\title{
'Hand Catch Operation' on Corruption Crimes: The Case of the KPK in Indonesia
}

\author{
Hendrik Dengah", M. Syukri Akub, Slamet Sampurno, Syamsuddin Muchtar \\ Faculty of Law, Hasanuddin University, Makassar, Indonesia \\ ${ }^{*}$ Corresponding author
}

\begin{abstract}
This paper examines the effectiveness of anticorruption law enforcement functions of the Indonesian Corruption Eradication Commission. Type of the research was an empirical legal research. The research was conducted in the Office of the Indonesian Corruption Eradication Commission, the Indonesian National Police, and the Attorney General's Office of the Republic of Indonesia, Jakarta. The results show that the investigations carried out by the Indonesian National Police and the Indonesian Corruption Eradication Commission at this time, must be recognized as not optimal, given that there are still various factors that are obstacles in the investigation process of the corruption crime. The main factor of the aspect of formal legal substance which is multiple interpretations in the formulation of corruption offenses, including the interpretation of 'Hand Catch Operations' from various approaches. The legal structure aspect is mainly related to investigative institutions that are not yet integral, with a system of coordination that is not yet synergic and harmonious, while the legal culture aspect is mainly not yet established the support of anticorruption community participation in efforts to eradicate corruption.
\end{abstract}

Keywords: Corruption; Criminal Law; Hand Catch Operation; KPK

DOI: $10.7176 / J L P G / 81-15$

\section{Introduction}

The discourse on anti-corruption approaches during the last decade has been increasingly discussed. The increase in uncontrolled corruption has a negative impact on the national economy and the quality of public services that tend to be ease-oriented. ${ }^{1}$ Widespread and systematic corruption is also a violation of social rights and economic rights of the community, therefore corruption can no longer be classified as ordinary crime but has become an extraordinary crime.

Efforts to eradicate criminal acts of corruption can no longer be carried out in the usual way like handling other common crimes, but must be pursued through extraordinary methods. Efforts to uphold the criminal acts of corruption that have been carried out so far have experienced various obstacles and often lead to the failure of the apparatus to disclose the main perpetrators (dader) due to the lack of evidence. For this reason, an extraordinary law enforcement method is needed so that the eradication of corruption can be carried out optimally, intensively, effectively, professionally and sustainably, which not only reveals only the supporting actors but also the main actors in a criminal act of corruption.

The Indonesian Corruption Eradication Commission (known in Indonesia as Komisi Pemberantasan Korups $i[\mathrm{KPK}])^{2}$ is the state institute in conduct its duties and authorities are independent and must be free from any influence, it is similar to other institutions have the authority to carry out duties and its objectives. In outline, the authority of the Corruption Eradication Commission in Act No. 30 of 2002 on the Corruption Eradication Commission can concluded with the details; the authority as duties of the Corruption Eradication Commission, the rights to exercise authority, the authority relating to technical implementation

\footnotetext{
${ }^{1}$ Asian Development Bank (ADB), 2000, Anti-Corruption Policy; Description and Answers to Frequently Asked Questions, Manila, Philippines, p. 16

${ }^{2}$ The Komisi Pemberantasan Korupsi (KPK) is the Indonesian Corruption Eradication Commission, which was formed after special consideration on the extraordinary nature of corruption in Indonesia, which has become systemic and widespread, and has violated the human rights of the Indonesian people. The KPK was formed under Act No. 30 of 2002 on the Corruption Eradication Commission.
} 
of duties and others.

Indeed, from the aspect of formal crime legal, ${ }^{1}$ the handling of special crimes, the police have the authority as the investigation and investigator bodies ${ }^{2}$ although it has itself regulation, not many differences in the handling of corruption special criminal of the police and the prosecution institute, including ad hoc institution such as Corruption Eradication Commission.

One particularity of the Act of the Eradication of Corruption concerns the material criminal law of gift and receipt of gratification. Regulatory review that gratification can be considered bribery act, if it associated with his/her position and contrary to his/her obligations and duties. In other words, gratification has a negative impact and can be abused, especially in service delivery for the public sector in the government, so entered into the legislation concerning corruption crime. Correspondingly, when observe the implementation of duties for the third of law enforcement agencies above, the handling of corruption associated with the gratification, can be ascertained that the Corruption Eradication Commission is a body of investigation, investigator and prosecutor are very prominent and optimized to eradicate gratification in law enforcement for corruption cases.

While the perpetrators of corruption who are increasingly brave in carrying out their actions encourage the KPK to take the right steps. The KPK also held 'Hand Catch Operation' (hereinafter abbreviated as 'OTT'). In 2016, for the first time, the KPK held OTT outside Java, such as in Riau, Sulawesi, even in Buol. This clearly confirms that the KPK's reach is not limited to Java. In addition to having an impact that creates fear for certain subjects, OTT is also an effective way to initiate the investigation of corruption. Acting with this method is actually a form of the KPK's response to the enthusiasm of people who have reported corruption. $^{3}$

In conducting OTT, there are two techniques used by the KPK, namely tapping and entrapment. ${ }^{4}$ This has implications for the use of these two techniques which often lead to opinions that the KPK violates law and human rights. The tapping technique carried out by the KPK is only regulated in general in the provisions of Article 12 paragraph (1) of Law No. 30 of 2002, while entrapment is unknown in various rules regarding corruption in Indonesia. One of the actions of an investigation is gathering information through surveillance and wiretapping. The KPK Law authorizes KPK investigators to tap telephone conversations even though the case is still under investigation, not only in the investigation or pro justicia stage. ${ }^{5}$

In the context of criminal law, crime of bribery (reading corruption) is a simple but difficult crime to prove. Usually between bribes as causal proxies and recipients of bribes always carry out a silent operation to realize these crimes. Even if possible remove the evidence that the crime has been committed. Therefore, to eradicate corrupt practices in the form of bribery must be done with silent operation as well. It cannot be denied that the disclosure of several cases involving politicians and top officials of the state is inseparable from the KPK's arrest operation. ${ }^{6}$

Hand Catch Operation carried out by the KPK should have received appreciation from various parties for being able to ensnare various perpetrators of corruption. The use of tapping and entrapment techniques results in the disclosure of various corruption cases whose perpetrators are State Officials in the country. Nevertheless, entrapment which is one of the effective techniques for ensnaring perpetrators of corruption is still not having strong legitimacy in our national law. The use of these techniques often leads to debate, especially concerning issues of violation of law and human rights.

\section{Method of the Research}

Type of the research was an empirical legal research. The research was conducted in the Office of the Indonesian Corruption Eradication Commission, the Indonesian National Police, and the Attorney General's Office of the Republic of Indonesia, Jakarta. Then, the data obtained in this research is described

\footnotetext{
${ }^{1}$ Formal criminal law contains regulation that regulates how the criminal law that is abstract must be applied in concrete. Often, the person mentions the type of this law as criminal law in P.A.F. Lamintang, (1984). Dasar-Dasar Hukum Pidana Indonesia, Bandung: Sinar Baru, p.10

${ }^{2}$ Article 5 and 7 Act No. 8 of 1981

${ }^{3}$ Annual Report. KPK Tahun 2012. "Tetap Optimal dikala Minimal”. p. 45.

4 Luthvi Febryka Nola. (2013). Operasi Tangkap Tangan Oleh KPK. Jurnal Info Singkat Hukum Vol. V, No. 24/II/P3DII/Desember/2013. p. 3.

${ }^{5}$ Anton Septian. "Penyadapan, Kunsi Operasi Tangkap Tangan KPK”, Koran Tempo, June 22, 2015. p. 5.

${ }^{6}$ Eddy Os Hiariej. “Operasi Tangkap Tangan” Koran Kompas Tanggal 7 Oktober 2013, p. 7.
} 
in accordance with the problems studied in descriptive qualitative. The primary and secondary legal materials that have been collected are inventoried, processed and studied in depth so as to obtain a description of the legal issues.

\section{6. 'Hand Catch Operation' and Corruption Prevention: A Critical Overview}

Corruption is commonly understood as the abuse of public office for private gain. ${ }^{1}$ It "involves behavior on the part of officials in the public and private sectors, in which they improperly and unlawfully enrich themselves and/or those close to them, or induce others to do so, by misusing the position in which they are placed". Therefore, a corruption is a form of seeking personal gain.

The Indonesian Corruption Eradication Commission has a system for dealing with corruption cases, namely Hand Catching Operations (OTT), in carrying out capture operations there are two techniques used by the $\mathrm{KPK}$, namely tapping and entrapment, but entrapment is not regulated in any applicable law. The handling of corruption will face the problem of limited capacity, given the type or quality of the target (ie corruption) which is not an arbitrary crime (from the point of view of the perpetrator, the modus operandi) often categorized as Crime White Collar Crime. Tapping is only regulated generally in Law Number 30 of 2002, while entrapment is not known in various rules regarding corruption in Indonesia. As a result, the two techniques often lead to opinions that the KPK violates law and human rights. The lack of clarity regarding the mechanism and limits of the wiretapping authority carried out by the KPK raises the public assumption that the tapping authority by the KPK has violated the law and even violated human rights, namely violating one's privacy rights.

The KPK was formed basically not to take over the task of eradicating corruption from existing institutions. Explanation of the law mentions the role of the KPK as a Trigger Mechanism, which means encouraging or as a stimulus so that efforts to eradicate corruption by existing institutions become more effective and efficient. In the context of criminal law, bribery crime is a simple but difficult crime to prove. Usually, between bribes as Causa Proxima and bribe recipients always do Silent Operation to realize the crime. ${ }^{2}$ Even if possible remove the evidence that the crime has been committed. Therefore, to eradicate corrupt practices in the form of bribery must be done with Silent Operation as well.

In the context of the burden of proof, there are a number of records related to the capture operation: ${ }^{3}$ First, there are differences in the principle of proof in civil and criminal cases. In civil cases, the parties that engage in civil law tend to hold evidence with the intention that if a dispute arises in the future, the parties will submit evidence to strengthen their argument in court. This is different from criminal cases, where the perpetrator always tries to negate the evidence or erase the trace of the crime committed. Hand capture operations are more effective in proving crimes that are difficult to prove, including corruption crimes.

Second, in proving criminal cases there is a postulate that reads in Criminalibus Probantiones Bedent Esse Luce Clariores, that in criminal cases, the evidence must be brighter than light. That is, to prove someone as an offender is not only based on suspicion, but the available evidence must be clear, clear, and accurate.

Third, in the context of corruption crimes, capture operations are definitely preceded by a series of wiretapping actions that have been carried out within a certain period of time. The result of tapping is basically the initial evidence of a criminal offense if there is one proof and the other evidence is conformity (Corroborating Evidence). Hand capture operations are only to concretize a series of wiretapping actions that have been carried out beforehand so that the preliminary evidence that has been obtained will be sufficient proof of the beginning. It means, the case is ready to be processed in a criminal manner because it has at least two evidences.

Fourth, in the context of the power of proof, catching operations can be said to fulfill perfect proof (Probatio Plena). That is, the evidence no longer raises doubts about the involvement of the perpetrator in a crime. Nevertheless, the judge in the criminal case is not absolutely bound to any evidence. However, the capture operation can at least eliminate these doubts. The policy of the KPK in dealing with corruption through Hand Operations in uncovering corruption cases was supported by tapping techniques.

\footnotetext{
1 Choi, J. W. (2011). Measuring the performance of an anticorruption agency: The case of the KPK in Indonesia. International Review of Public Administration, 16(3), 45-63.

${ }^{2}$ Tjiptoherijanto, P. (2009). Corruption Prevention in Indonesia. Indonesia University, available at: http://unpan1. un. org. p. 2

${ }^{3}$ Interview with Mr. Yadin, Attorney of the KPK, October 12, 2018.
} 
Therefore, the tapping of the KPK can only be considered as a violation of the law when the tapping process is not carried out by an authorized official, for example, the KPK conducts eavesdropping even though he is not a KPK investigator who is examining a case. This is because in Article 12 paragraph (1) letter (a) of the KPK Law it is stated that in the matter of investigation and investigation the KPK has the authority to wiretap. The authority to conduct tapping is not in the institution (KPK) but for KPK investigators who are examining a case.

Research carried out by ICW during 2017 stated that the average verdict from court related to corruption cases was only 2 years 2 months. This fact is certainly very sad. The low ruling on the country's money was strongly related to the standard of prosecution and the verdict of prosecutors and judges. The average demand from prosecutors is around 3 years 2 months. The low prosecution of these prosecutors, coupled with mitigating considerations from the judges of the defendants of corruption, caused the convictions received to be very low. ${ }^{1}$

According to the authors, the ICW findings above should not be ignored. It must be realized that the low verdict of the judges on these corruptors is a big problem that makes corruption difficult to lose and even tends to be more fertile in the Mother Earth. One of the proofs is that we have stepped in more than four months in 2018, almost every week we hear the KPK arresting regional heads in hand-holding operations (OTT) as a result of being involved in corruption cases. Whatever the motivation of the KPK's steps, we must be concerned that efforts to eradicate corruption are still far from being burned.

One of the main factors of people committing corruption is that the law enforcement is not strict, including the severity of the punishment given. Because with such conditions, corruptors will risk taking corruption. With a relatively mild verdict that will not create a deterrent effect and corruption will continue to repeat itself. And, it will be a bad precedent for the nation's journey going forward if this phenomenon is left unchecked. Not to mention the perception of the international community towards this country. The OTT case against massive regional heads in 2018 helped to worsen Indonesia's image, including reducing investor confidence in coming to invest in Indonesia.

All components of the nation must agree that corruption is a common enemy that must be resisted. There should not be the slightest word of compromise for crimes that damage this nation. All must be made aware that corruption has made a large number of poverty in this country. We are a nation rich in natural resources, but unfortunately the distribution of national economic cakes is still uneven. Corruption has caused a higher gap in this republic. Only one solution is to make this country fair and prosperous, namely by eradicating corruption seriously. Everything must be brushed off, especially the big-time corruptors who are a lot to the detriment of this nation. KPK, Police, Attorney General's Office, and the Judges must be one word to be strict with corruptors. On the other hand, the intention to sink the KPK in the midst of the increasingly violent wave of corruption cannot be considered a political sensation anymore. The more days the voices that wanted the anti-racial institutions to be disbanded were only increasingly loud. Even DPR leaders such as Fachri Hamzah brightly requested that the KPK be closed down.

The establishment of the KPK is actually unnecessary if only law enforcement institutions such as the National Police, prosecutors and judiciary are able to do so. The KPK also does not need to be armed with three authorities, investigation, prosecution and if only the three institutions were able to prove themselves sterile from the virus of corruption. In fact, instead of arresting corruptors, a number of individuals from institutions funded by state money actually took away state money. Even so, the author wants to reveal the perspective of another story from Corruption. Seated between the matter of Corruption and Scientific International Relations is intended to find a kind of concrete resolution. Above all, as understood, Corruption in its area, no longer attacking one country, but endemic in almost all countries of the world, however, its intensity is different.

The eradication of corruption in Indonesia must be truly based on a shared responsibility to see a sovereign Indonesia that is just and prosperous, in accordance with the ideals of the 1945 Constitution. The intermestic approach is the basis for us to move in eradicating corruption. Issues in the international world are in line with what is happening in the country's domestic sphere. As good and strong as any International Law that is formed if from within the country itself, there is less supervision and eradication of corruption that seems half-hearted and still will not succeed. Law enforcement agencies and apparatus in eradicating corruption must be truly independent, free from the influence and interests of a handful of people who want

\footnotetext{
${ }^{1}$ SINDO News, Friday, 4 May 2018.
} 
to perpetuate corruption in Indonesia. International policy and law are complementary instruments, to improve corruption eradication. The main key is in the leaders and all the people of Indonesia.

\section{The Ideal Concept of Eradicating Corruption Crime by the Indonesian Corruption Eradication Commission}

Corruption also means it can be bribed, either in cash, or in the form of certain objects. Corruption is an act that violates the law or norms related to the duties and responsibilities of civil servants or state officials. Besides, the corruption usually involves more than one person. Corruption is not only applicable in the civil service or state officials, but corruption can involve private business organizations. ${ }^{1}$ Corruption as a form of bad conduct, evil and destructive, actually has a very broad sense. Forms of corruption can be misappropriation or embezzlement of state funds for personal interests or others. All of these are characteristic or distinctive character of corruption.

In fact, it regarded that corruption has become part of the culture of the nation. The others believe that corruption is like an endemic disease that has spread throughout the level of government bureaucracy. To restore such losses, juridical means is required in the form of compensation payment or compensation. In such situation, if the corruptor benefits from their actions, then the results of crime are transferred to the other party and the other party to another party again then the property cannot be seized, especially if the asset is hidden through the banking system. Article 480 of the Criminal Code (Buyer of stolen goods) has limitations, because this provision only regulates if the transfers are objects, not money.

Theoretically, there are many notions of corruption depend on the perspective where a person would perceive it. Corruption can be seen from the perspective of legal, economic, and political. However, to distinguish it from other ordinary criminal offenses, which are not included in the category of corruption, the definition of corruption must be placed in the public domain, so that the understanding of corruption is always related to the public interest. In this case, corruption is an act that is contrary to the public interest or the interests of the state in general. This is one of the basic characteristics possessed by corruption as an extraordinary crime, so it is different from an ordinary theft or fraud is simply subjected at individual persons. Thus, corruption is to be seen in the context of the public interest.

This systemic approach can be used as material for solving legal issues or legal solution as well as a legal opinion. The system as a type of unit has a certain order. In this case, the order to show to a structure composed of parts. And also, system is a plan, method or procedure to conduct something. And the system can be formulated as a complex whole, integrated, characterized by elements that interact, which is aimed to achieve certain goals, where the system affecting one another.

If elaborated, elements that create a legal system includes: ${ }^{2}$ First, the element of ideal, it is formed from the meaning system of legal, consisting of rules, norms, and principles; Second, the element of operational, it consists of all the organizations and institutions, which is established in a legal system. Included in this element is a position holder (ambtsdrager), which functions within the framework of an organization or institution; Third, the element of actual, is overall decisions and concrete actions related to the meaning system of legal, both from the position holder nor citizens, in which there is the legal system.

Regarding the legal system, Friedman stated that the legal system is composed of 3 (three) elements, namely legal structure, legal substance, and legal culture. ${ }^{3}$ The legal structure is a pattern that shows how the law was implemented according to the provisions formally, which shows how the legal process run by law enforcement officials; The legal substance is a rules used by the legal actors at the time of deeds and legal relations; whereas legal culture is a demand or request that requires solving of legal issues through legal institutions. ${ }^{4}$

Indonesian national legal system is a legal system that applied in throughput Indonesia that includes all legal elements (such as content, structure, culture, facilities, legislation, and all sub-elements) and one another are interrelated and sourced from the preamble and articles of the 1945 Constitution. Refers to Friedman's theory about the legal system, the legal system is divided into 3 (three) elements namely the

\footnotetext{
1 Edi Suandi Hamid and Muhammad Sayuti (Ed). (1999). Menyingkap Korupsi, Kolusi, Nepotisme di Indonesia, Aditya Media, Yogyakarta, page. v

2 Ibid, Pages 140-141

3 Satjipto Rahardjo. (2000). Ilmu Hukum. Bandung: PT.Citra Aditya Bhakti, p 154.

${ }^{4}$ Ibid, Page 154.
} 
substance (material/substance), structure, and culture. ${ }^{1}$

The potential for corruption in an area in the project of goods or services procurement is quite possible. In essence, ${ }^{2}$ the corruption crime has been carried out by law enforcement officers such as Police, Attorney and Corruption Eradication Commission. Related to the existence of Police as one institution given the duties, functions and authority to conduct investigations on corruption case in Indonesia, by itself demanded the investigators of Police to more improve performance and professionalism in investigation, so that the results achieved from the investigation become an integral part of the action aimed at eradicating the corruption in Indonesia.

The establishment of a special institution to address the Corruption in Indonesia is actually not a new one. However, the establishment of a special institution with such broad authority, in addition to conducting investigations, and prosecution in corruption cases, noteworthy as an aspect of reform in the law and the criminal justice system in Indonesia.

The political will to establish such specialized institution cannot be separated from the initial consideration to overcome the corruption eradication that cannot be implemented optimally. Law enforcement agencies were there, who had been assigned the duty and authority to address the corruption has not been functioning effectively. While, corruption itself has such place in society, and has been conducted in a systematic and widespread, and thus perceived to have violated the social and economic rights in the communities, as part of human rights. As a result of corruption in such a way, including corruption among law enforcement itself there are doubts or even distrust and apathy of society towards the effective functioning of the criminal justice system of Indonesia in eradicate corruption.

Criminal justice is a process in which there are multiple agencies or law enforcement agencies and their apparatus is working together in accordance with the duties and authority. Therefore, criminal justice can be understood as a process involving activities or activities of the criminal justice agencies. Activities within the process itself are a gradual and sustained activity that starts from the activities of investigation, prosecution, inspection at the trial, and ends with the judge's decision. The sustainable activities were performed by different law enforcement agencies are administratively and structurally. The activity of investigation is conducted by the police and judiciary by the prosecutor. While, at the trial conducted by the court, and the enforcement activities carried out by the penitentiary. Nevertheless, functionally the law enforcement agencies are one another as an integral part and must cooperate within the framework of system; the criminal justice system.

The criminal justice process in Indonesia for decades is characterized by the dualism of investigative authority. In general, statute laid investigative authority to the police, so that in practice the term "single investigator" emerges. This means that the police are only law enforcement authorized to conduct an investigation in any criminal. Article 6, paragraph (1) of Criminal Code determines investigators are (a) the State Police of the Republic of Indonesia; (b) certain civil servants who were given special authority by law. Meanwhile, the law still recognizes the existence of investigation authority on the special criminal of judiciary under the provisions of a special criminal law itself. The juridical foundation is the provisions of Article 284 paragraph (2) Criminal Code that specifies:

Within two years after the legislation is enacted, it is against all cases apply provisions of this law, with the exception for a while about the specific provisions of criminal procedure as mentioned in certain laws, until there is an amendment and/or no longer valid.

On the basis of the provision of special criminal laws (e.g corruption laws), the judiciary considers investigative authority against corruption is a monopoly its institution. Functionally, the collision of authority to investigate, it describes the tendency toward the agency-centric. Such way of thinking is clearly not desired, and may damage the criminal justice as a system. In addition, a way of thinking that is agencycentric has enough to describes that the conception of "integrated criminal justice system" have not been implemented in the criminal justice process, because the desired concept is the creation of a close cooperation between the subsystem of criminal justice itself.

In the context of integrity, the criminal justice process should be avoided independent attitude which can damage the work or criminal justice process as a system. That independence occurs when a subsystem

\footnotetext{
${ }^{1}$ Harian Kedaulatan Rakyat, Hukum Nasional Menganut Prismatik Pancasila, 11 September 2006, p. 21.

${ }^{2}$ Roy, Subir Kumar. (2016). "Consumer Justice: A Symbol of Economic Prosperity and Social Progressiveness." Hasanuddin Law Review, 2(2): 170-181. DOI: http://dx.doi.org/10.20956/halrev.v1n2.302.
} 
assumes other subsystem as a separate environment, so that they would not work together as a system. They merely pay attention or thinking about work or the work of their own institutions without regard to how the influence of the institution works on the work of other agencies. Such attitudes that is referred to as agency-centric way of thinking and fragmentary, and undesirable in the conception of "integrated criminal justice system".

Normatively, Police, Judiciary and the Commission are merely conduct legislation to investigate the corruption in order to eradicate corruption, but functionally always conflicts and pull investigative authority and way of thinking that are agency-centric. This method is clearly undesirable and this can inhibit the work or process of criminal justice as a system. The collision of the investigation, agency-centric way of thinking clearly does not support efforts to eradicate corruption and consequently the effectiveness of integrated anti-corruption cannot be expected maximally. Even though normatively regulated corruption eradication in an integrated manner, it is obviously not effective because it is constrained by functional, structural and administrative.

The image of unity in the process of the criminal justice system should be a silk thread to search all phases of the criminal case investigation since the beginning until the end of criminal course by defendant. Therefore, the law enforcement agencies as an independent body administratively, but functionally they must describe the image of unity. It can be concluded that the integration in the criminal justice system should be reflected in the principle of unity in the unity of diversity towards a common goal, namely overcoming the crime, especially corruption.

The collision between various law enforcement agencies, as described above may be said to have occurred a phenomenon that significantly coloring the criminal justice process in Indonesia. The phenomenon should be recognized, because each agency is administratively and institutionally is stands alone. Therefore, each agency has a way to work or on their own method in implementing its duties and authority in accordance with applicable regulations.

The situation become so not-conducive in the applicable legal culture, which law enforcement officers do not have a common vision and perception in implementing the provisions of the applicable law, so that each has its own view of their duties. Sometimes, it is possible that the legal culture is defeated by other factors outside the law. And also with the weak of judiciary and police legislation formulation, which tend to overlap (collision) in formulating investigative authority.

To minimize the possibility of such collisions, theoretically need to consider three-pronged approach in the criminal justice system namely: normative, administrative and social approach. Normative approach is an approach that view four law enforcement agencies (police, judiciary, courts, and correctional institutions) as the implementing agency of legislation in force, so the four apparatus is an integral part of the law enforcement system.

It is clear that the role of moral is greater in efforts to eradicate corruption. Similarly, the measures that can be taken to civilize something useful in effort to eradicate corruption, namely through education, then an effort to promote morale are determined by the education comprehensively and simultaneously both formal and informal. Here, needed participation for religious leaders to playing an important role and assist the government in implementing educational packages of religious and ethical values.

\section{Conclusion}

Investigations carried out by the Indonesian National Police and the Indonesian Corruption Eradication Commission at this time, must be recognized as not optimal, given that there are still various factors that are obstacles in the investigation process of the corruption crime. The main factor of the aspect of formal legal substance which is multiple interpretations in the formulation of corruption offenses, including the interpretation of 'Hand Catch Operations' from various approaches. The legal structure aspect is mainly related to investigative institutions that are not yet integral, with a system of coordination that is not yet synergic and harmonious, while the legal culture aspect is mainly not yet established the support of anticorruption community participation in efforts to eradicate corruption.

To minimize corruption, it is recommended that a minimum punishment against corruptor can be avoided

\footnotetext{
${ }^{1}$ Barda Nawawi Arief. (2011). Kapita Selekta Hukum Pidana tentang Sistem Peradilan Pidana Terpadu (Integrated Criminal Justice System). Semarang: Diponegoro University Press, pp 26-27
} 
by the judge, because it is not deterrent for corruptor and not to scare potential perpetrators of corruption. Moreover, the minimum punishment actually grows corruption. In addition, legal guarantees are needed for people who report suspected corruption. If we expect the eradication of corruption can be implemented optimally, it is recommended that the coordination between law enforcement agencies in the integrated criminal justice system is necessary to build their common vision, interpretation and perception in the implementation of the duties for the institution authorized to eradicate corruption.

\section{References}

Annual Report. KPK Tahun 2012. "Tetap Optimal dikala Minimal”.

Anton Septian. “Penyadapan, Kunsi Operasi Tangkap Tangan KPK”, Koran Tempo, June 22, 2015.

Asian Development Bank (ADB), 2000, Anti-Corruption Policy; Description and Answers to Frequently Asked Questions, Manila, Philippines.

Barda Nawawi Arief. (2011). Kapita Selekta Hukum Pidana tentang Sistem Peradilan Pidana Terpadu (Integrated Criminal Justice System). Semarang: Diponegoro University Press, pp 26-27

Choi, J. W. (2011). Measuring the performance of an anticorruption agency: The case of the KPK in Indonesia. International Review of Public Administration, 16(3), 45-63.

Eddy Os Hiariej. “Operasi Tangkap Tangan” Koran Kompas Tanggal 7 Oktober 2013.

Edi Suandi Hamid and Muhammad Sayuti (Ed). (1999). Menyingkap Korupsi, Kolusi, Nepotisme di Indonesia, Aditya Media, Yogyakarta.

Harian Kedaulatan Rakyat, Hukum Nasional Menganut Prismatik Pancasila, 11 September 2006.

Luthvi Febryka Nola. (2013). Operasi Tangkap Tangan Oleh KPK. Jurnal Info Singkat Hukum Vol. V, No. 24/II/P3DII/Desember/2013.

P.A.F. Lamintang, (1984). Dasar-Dasar Hukum Pidana Indonesia, Bandung: Sinar Baru.

Roy, Subir Kumar. (2016). "Consumer Justice: A Symbol of Economic Prosperity and Social Progressiveness." Hasanuddin Law Review, 2(2): 170-181.

Satjipto Rahardjo. (2000). Ilmu Hukum. Bandung: PT.Citra Aditya Bhakti.

Tjiptoherijanto, P. (2009). Corruption Prevention in Indonesia. Indonesia University, available at: http://unpan1. un. org. 